\title{
3 Research Square

\section{Association between serum zonulin level and severity of house dust mite allergic asthma}

\section{Shereen A. Baioumy}

Zagazig University Faculty of Human Medicine

Shereen Mahmoud Ibrahim

Zagazig University Faculty of Human Medicine

Aya Elgendy

Ain Shams University Faculty of Medicine

Shaimaa Hani Fouad ( $\square$ shaimaahani@med.asu.edu.eg)

Ain Shams University Faculty of Medicine https://orcid.org/0000-0003-4052-9454

\section{Research}

Keywords: Asthma, Zonulin, Asthma grade, Severity, House dust mites, Intestinal Barrier

Posted Date: May 13th, 2021

DOI: https://doi.org/10.21203/rs.3.rs-492455/v1

License: (c) (i) This work is licensed under a Creative Commons Attribution 4.0 International License. Read Full License 


\section{Abstract}

\section{Background:}

Increased intestinal permeability, either due to the exposure to antigens in asthmatic patients or due to a barrier defect, play a critical role in susceptibility to environmental allergens. House dust mites allergy occurs more commonly than any other allergens among Egyptian asthmatic patients.

\section{Aim:}

To assess the relation between serum zonulin level as a marker of increased intestinal permeability and the severity of house dust mites allergic asthma.

\section{Methods:}

A case control study which included 48 house dust mites allergic asthma and 48 healthy control subjects attending the allergy and immunology unit, microbiology and immunology department, Faculty of medicine, Zagazig University.

\section{Results:}

On comparing the 2 studied groups, there was a statistically significant difference between the 2 groups concerning serum IgE and serum zonulin levels ( $p=0.000,0.000$ respectively)The mean serum zonulin was equal to $258.3 \pm 153.01 \mathrm{ng} / \mathrm{ml}$ in the asthmatic group and $80 \pm 13 \mathrm{ng} / \mathrm{ml}$ in the control group. Serum zonulin level significantly increased with the increase of asthma severity ( $\mathrm{p} \otimes 0.001)$. The cut off value of serum zonulin was $\geq 198 \mathrm{ng} / \mathrm{ml}$, and the area under the curve was 0.76 . It displayed sensitivity equal to $80 \%$ and specificity equal to $71.4 \%$. Its negative predictive value was equal to $83.3 \%$.

\section{Conclusion:}

Intestinal barrier dysfunction contributes in the pathogenesis of allergic asthma. Serum zonulin level reflects an increase in intestinal permeability and acts as prognostic factor of severity in Asthma. Correction of the gut barrier defect may be an additional novel approach for Asthma.

\section{Introduction}

Asthma is a common chronic airway disease characterized by airway inflammation, hyperresponsiveness, and variable airway obstruction, which is often attributed to gene-environment interactions [1].

Epidemiologic studies have shown that sensitization to indoor allergens is an important risk factor for the occurrence of acute attacks of asthma[2].

The most prevalent indoor allergens include house dust mites (HDMs), animal dander, moulds and cockroaches. Of these, HDMs, especially D. pteronyssinus and D. farinae, are considered the major perennial indoor allergen sources inducing allergic sensitization worldwide [3]. 
Environmental factors, microbiome, epithelial cells and immune cells show a dynamic cross talk at the skin and mucosal barriers in the development of atopic dermatitis, allergic rhinitis, eosinophilic esophagitis and asthma.[4]

Recent trends in targeting allergic disorders are directed towards personalized medicine approach which necessitates novel developments in the area of disease phenotyping, endotyping, and the development and application of reliable biomarkers.[4]

Increased intestinal permeability due to the exposure to antigens in asthmatic patients may play a role in susceptibility to environmental allergens. Therefore, correction of the gut barrier defect may be an additional novel approach for asthma treatment.[34]

More than 50 proteins act together to create effective tight junctions which are crucial to having an efficient gut mucosal barrier. A $47 \mathrm{k}$ Da protein named Zonulin enhances and reversibly alters intestinal permeability. It also shares in innate intestinal immune response. An increase in serum Zonulin level has been reported in many autoimmune diseases in which a defective intestinal barrier plays a role in their pathogenesis.[5] Chronic inflammation due to environmental stimuli results in up-regulation of serum zonulin .An increase in serum Zonulin was noticed to be significantly correlated to disease severity in atopic dermatitis patients.[6]

\section{Patients And Methods}

This is a case control study which included 96 subjects attending the allergy and immunology unit, microbiology and immunology department, Faculty of medicine, Zagazig University.

\section{Sample size:}

Assuming that serum zonulin level in case group versus control group is $(11.3 \pm 3.7 \mathrm{ng} / \mathrm{ml})$ and $(9.3 \pm 3.3$ $\mathrm{ng} / \mathrm{ml}$ ) respectively with confidence level $95 \%$ and power $80 \%$. So the sample size is 96 (48 in every group)

They will be divided into 2 groups.

Group 1 (Control group): includes 48 healthy controls who fulfilled the same exclusion criteria as the patients, and never had asthma or eczema.

Group 2 (Asthmatic patients): includes 48 adult ( $\geq 18$ years old) subjects with allergic asthma according to Global Initiative for asthma consensus report (GINA), 2020. [7]

\section{Inclusion Criteria:}

Allergic asthma patients were selected as having:

- Obstructive pattern; Low FEV1/FVC on pulmonary function test:

- Allergy as positive skin prick test for house dust mites.

\section{Exclusion Criteria:}


1-Evidence of digestive disease

2-Any other condition associated with increased intestinal permeability, such as cystic fibrosis,

3- Food allergy or patients having positive skin test against common food allergens.

The control subjects fulfilled the same exclusion criteria as the patients, and never had asthma or eczema.

4- Patient refusal to participate.

The control subjects fulfilled the same exclusion criteria as the patients, and never had asthma or eczema.

\section{Each patient was subjected to the following:}

1-Full detailed history and examination to exclude any comorbid condition that may affect the result of the study.

2-Full detailed allergic history and clinical examination of the respiratory system

3-Chest x ray was done to exclude other lung pathology.

4- Pulmonary function tests with special emphasis on FEV1, FEV1/FVC using SPIROMETRICS

5- Total serum IgE was done for each patient using enzyme-linked immunosorbent assay (ELISA).

6- Skin prick testing to common allergens.

7-Asthma severity score was calculated according to GINA, 2020. [7]

8- Serum zonulin level detection by ELISA

\section{Asthma severity scoring:}

Asthma was divided into grades I-IV (I being the mildest and IV the most severe). Grading was based on events that occurred over the past six months; including day and night symptoms, effect of asthma on daily activity, use of steroids, and peak expiratory flow rate as defined by GINA guidelines 2020. Pulmonary function tests were performed for all patients using a fully computerized Spirometer (Jaeger MasterScreen ${ }^{\mathrm{TM}}$ IOS, version 5.2 manufactured by VIASYS Healthcare $\mathrm{GmbH}$, Hoechberg, Germany) Pulmonary functions were assessed using forced expiratory volume in 1 second (FEV1), forced vital capacity (FVC) and the FEV1/FVC ratio, measured and expressed as a percentage of predicted values with a ratio higher than 0.8 being normal.

\section{Skin testing:}

- Skin testing was performed according to Bernstein et al., 2008. [8]

- Allergen extracts of skin testing were standardized allergen extracts provided by Hamilton (Omega, Allergy OVERSEAS consultant Inc., Canada). The test was performed using the following allergens: for 
aeroallergens: (house dust mite; Dermatophagoides (D.)pteronyssinus and Dermatophagoides (D.) farnae mites; grass, mixed pollens; mixed molds, tobacco, cotton, wool, cockroach, hay dust) and food allergens: (egg, fish, peanuts, cows' milk).

- Histamine dihydrochloride $(10 \mathrm{mg} / \mathrm{ml})$ was used as a positive control, while saline was used as a negative control.

- Subjects were asked to stop antihistamines a week before skin testing.

- The largest diameter of the wheal was measured, and it was considered positive if it was $\geq 3 \mathrm{~mm}$ (ASCIA guidelines, 2020). [9]

- Those with positive tests for food allergy were excluded from the study.

\section{Sample collection:}

Five $\mathrm{ml}$ blood were collected by venipuncture under complete aseptic conditions. Samples were left to clot then centrifuged at $1000 \mathrm{xg}$ for 15 minutes. Sera were collected and stored at $-20^{\circ} \mathrm{C}$. Sera were used to measure serum levels of total IgE, and zonulin.

\section{Serum level of total IgE:}

Quantitative measurement of serum level of total IgE was done using a commercially available sandwich enzyme-linked immunosorbent assay (ELISA) Kit supplied by Chemux Bioscience, Inc. (CA, USA, Cat No.10602) according to the manufacturer's instructions. The results were expressed in IU/mL. The total IgE level in a normal, allergy-free adult is less than $150 \mathrm{IU} / \mathrm{ml}$ of serum. The minimum detectable concentration of $\mathrm{IgE}$ by this assay is estimated to be $5.0 \mathrm{IU} / \mathrm{ml}$. The Absorbance of standards and samples were measured at $450 \mathrm{~nm}$ using a microtiter plate ELISA reader (Biotek, USA).

\section{Measurement of serum zonulin level:}

Quantitative measurement of serum level of zonulin was done using a commercially available sandwich enzyme-linked immunosorbent assay (ELISA) Kit supplied by MyBiosource, Inc. (USA, Cat No: MBS774026) according to the manufacturer's instructions. The results were expressed in $\mathrm{ng} / \mathrm{ml}$. Absorbance of standards and samples were measured at $450 \mathrm{~nm}$ using a microtiter plate ELISA reader (Biotek, USA). The kit detection range was $20 \mathrm{ng} / \mathrm{ml}-800 \mathrm{ng} / \mathrm{ml}$.

\section{Statistical analysis:}

The collected data were processed and coded before being analyzed using SPSS program version 23 . Quantitative data were presented as minimum, maximum, mean and SD.

Qualitative data were presented as count and percentage.Student $t$ test was used to compare quantitative data between two groups and One Way ANOVA test was used to compare more than two groups.Pearson's correlation was used to measure linear relationship between two continuous variables.ROC curve was used to measure diagnostic validity of quantitative variables and linear regression test was used to measure 
independent effect of some factors on quantitative outcome variable.P value $<0.05$ was considered statistically significant.

\section{Results}

The current study was a case control study which included 96 subjects attending the allergy and immunology unit, microbiology and immunology department, Faculty of medicine, Zagazig University during the year 2021.They were divided into 2 groups, group 1 included healthy controls with a median age of 28 [ $\mathrm{n}=48]$ and group 2 included patients with allergic asthma according to Global Initiative for asthma consensus report (GINA), 2020 with a median age of 30 [ $n=48]$.

Regarding the asthmatic patients, the mean value of age was $30.67 \pm 15.609$, most of the patients were female (62.5\%) and most of them lived in rural areas (54.16\%). 39 patients (81.3\%) had positive family history of atopy. All patients displayed positive skin prick test results to house dust mites, most of the patients $(70.8 \%)$ were sensitive to $D$. pteronyssinus and $60.4 \%$ were sensitive to $D$. farina. 14 patients were mono sensitized to a single type of house dust mites and 34 patients were polysensitized to both types. As for the grade of asthma severity, 4 patients (8.3\%) had grade 1 severity, 24 patients (50\%) had grade 2 asthma severity, $12(25 \%)$ patients had grade 3 severity, and 8 patients (16.7\%) had grade 3 asthma severity. (Table 1)

Concerning the control group, the mean value of age was $32.7 \pm 11.2$, most patients were males $(85.3 \%)$ and $70.8 \%$ of them lived in rural areas. As per the family history of atopy, only $11(22.9 \%)$ patients had positive family history of atopy and all of them displayed negative skin prick test results.

On comparing serum total immunoglobulin $\mathrm{E}(\mathrm{IgE})$ level between asthmatic patients and control subjects, there was a highly statistically significant difference between both groups $(p=0.000)$. Asthmatic patients displayed a higher statistically significant level of serum total IgE. The mean serum IgE was equal to $233.3 \pm 103.4 \mathrm{IU} / \mathrm{ml}$ in the asthmatic group and $84.4 \pm 18.6 \mathrm{IU} / \mathrm{ml}$ in the control group. (Table 2)

Similarly, there was a high statistically significant difference between both groups as regards serum zonulin level. Asthmatic patients displayed a higher statistically significant level of serum zonulin than control subjects. The mean serum zonulin was equal to $258.3 \pm 153.01 \mathrm{ng} / \mathrm{ml}$ in the asthmatic group and $80 \pm 13$ $\mathrm{ng} / \mathrm{ml}$ in the control group. (Table 2)

Factors affecting serum total IgE level were male sex, asthma grade, and positive skin prick test. Male patients displayed a statistically significant higher serum total IgE level $(p=0.03)$. The mean value of serum total IgE was $272.89 \pm 141.33$ among male patients and was $193.53 \pm 56.38 \mathrm{IU} / \mathrm{ml}$ among female patients. Besides, post hoc test showed a significant difference between grade 1 vs grade 2 as regards serum total $\lg \mathrm{E}$. As the asthma severity increased there was a significant corresponding increase in the serum total IgE $(p=0.02)$. Moreover, there was a highly statistically significant difference as regards the mean value of serum total IgE between patients displaying positive skin prick test results and those displaying negative skin prick test results $(p=0.002)$ The mean value of serum total IgE among patients displaying positive skin prick test results was $244.41 \pm 114.85 \mathrm{IU} / \mathrm{ml}$. (Table 3 ) 
With regard to the correlation between serum zonulin level and seum total lgE, it didn't reach statistical significance $(p=0.34)$. (Table 4) Figure 2

As for the factors affecting serum zonulin level, they were residence and asthma grade. There was a statistically significant difference in the serum zonulin level between patients living in Urban areas and those living in rural areas. $(p=0.002)$ The mean value of serum zonulin was significantly higher in patients living in urban areas and it equaled to $315.55 \pm 157.34 \mathrm{ng} / \mathrm{ml}$. Post hoc test showed a highly statistically significant difference between grade 1 vs grade 2 , grade 1 vs grade 3 , grade 1 vs grade 4 , grade 2 vs grade 4 and grade 3 vs grade 4 as regards serum zonulin level (p®0.001). (Table 4) Figure 2

Grade of asthma had independent significant effect on zonulin level $(p<0.001)$ while serum total IgE had no significant effect on zonulin level via linear regression analysis ( $p=0.684 \mathrm{NS}$ ). ( Table 5)

Roc curve was done to assess the validity of zonulin level for differentiation between (grade 1 or 2) vs (grade 3 or 4$)(p=0.002)$. It displayed sensitivity equal to $80 \%$ and specificity equal to $71.4 \%$. Its positive predictive value was equal to $66.7 \%$ and negative predictive value was equal to $83.3 \%$. The cut off value of serum zonulin was $\geq 198 \mathrm{ng} / \mathrm{ml}$. The area under the curve was 0.76. (Table 6) Figure 3

\section{Discussion}

Asthma is a chronic inflammatory lung disease which is characterized by airway inflammation, intermittent airflow obstruction, and bronchial hyper-responsiveness.[10] Allergic asthma can be sparked by allergen sensitization in which house dust mites (HDM) are one of the most prevalent indoor allergens.[11] The prevalence of allergic sensitization is rising in developing countries, a phenomenon related to rapid urbanization and an adult's migration from a rural to an urban area increases their risk of sensitization to mite allergens. It also could contribute to a rapid increase of chronic respiratory diseases (CRD). Exposure to dust mite allergens is a risk factor for clinical asthma in sensitized subjects.[12]

The relationship between allergic asthma and intestinal permeability is a subject of research interest. An increase in the intestinal permeability may result in facilitating the entry of allergenic proteins from the intestinal lumen into the systemic circulation. Consequently, activation of the adaptive immune system, allergen sensitization and/or extra-intestinal inflammation occurs.[13]

The current study is a case control study that aimed at assessing the relation between serum zonulin level as a marker of increased intestinal permeability and the severity of house dust mites allergic asthma. Our study included 96 patients; 48 asthmatic patients and 48 control subjects. The mean age of the asthmatic patients ( $n=48$ ) was $30.67 \pm 15.609,30$ (62.5\%) were females and 18 ( $37.5 \%)$ were males and most of them, 26 patients, lived in rural areas (54.16\%). 39 patients $(81.3 \%)$ had a positive family history of atopy. All patients displayed positive skin prick test results to house dust mites, most of the patients (70.8\%) were sensitive to D. pteronyssinus and $60.4 \%$ were sensitive to D. farina. 14 patients were mono sensitized to a single type of house dust mites and 34 patients were polysensitized to both types. As for the grade of asthma severity, 4 patients (8.3\%) had grade 1 severity, 24 patients (50\%) had grade 2 asthma severity, 12 (25\%) patients had grade 3 severity, and 8 patients (16.7\%) had grade 3 asthma severity. 
Several studies supported these current results indicating that bronchial asthma was associated with females with an obvious sex bias. Ricciardolo FL et al., 2020 conducted a cross-sectional study on 499 asthmatic patients to assess the potential difference between asthmatic males and females in a real-life setting. Their study also displayed a female predominance in which 301 patients $60.32 \%$ were females.[14] In addition, Sabry, 2011 reported that $20-40 \%$ of asthmatic females of reproductive age suffer from worsening of their symptoms during their menstrual period, suggesting that sex hormones may have a major role in the biologic sex difference. [15].

These results could be attributed to hormonal factors, environmental exposure, and the presence of comorbidities. Since estrogen receptors (ERs) are highly expressed in the lungs and their smooth muscles with a special role in bronchoconstriction/dilatation, this explains the gender bias. Moreover, another possible hormonal factor is the lack of male sex hormone which plays an integral role in downregulation of innate and adaptive immune response.[16] Genetic factors may also be involved. The Cyclooxygenase (COX) pathways play an important role in the course of bronchial asthma and Cyclooxygenase-2(COX-2) gene homozygosity is related to females.[17]

In fact, rural residence has higher prevalence of parental smoking, higher number of siblings, advanced overcrowding rates, higher humidity levels and greater exposure to chemicals and farm animals.[18] Moreover, hot climatic conditions and high population density are crucial for the development and reproduction of mites[19]. Hence, the geographical situation of Egypt and its favorable climatic conditions together with its overpopulation contribute to the abundance of HDM especially in rural areas.[21]

The current results displayed that asthma patients were more commonly living in rural areas (54\%vs $45.84 \%$ urban asthmatics) and all of them had positive skin prick test response to house dust mites, DP;Df (70\%,60\% respectively). Lawson et al., 2017 likewise reported that children with asthma who lived in rural areas were more likely to wheeze or have more severe symptoms of wheeze. [20] Furthermore, this also agreed with Müsken et al., 2002 study which concluded that sensitization to storage mites in Germany was more frequently sensitive to D. pteronyssinus and the prevalence of positive skin test results to storage mites was greater in rural than in city dwellers. Also, In vitro sensitization to B. tjibodas mites was also significantly greater in rural than in city dwellers. [42] Besides, Hassan and Hagrass 2017 reported that house dust mites (HDM) allergy occurs more commonly than any other allergens among Egyptian asthmatic patients. [21]

Several studies disclosed that the high frequency of family history of allergy is common among asthmatics. Familial assemblage of asthma and allergic disease has frequently been observed, indicating that a positive familial history of atopy may be considered as an identifiable risk factor of asthma. This may be due to the evidence hinting that genetics play an essential role in the pathogenesis of asthma. In alliance, Antonios et al. 2012 reported $60 \%$ of cases had a positive family history and displayed $95 \%$ positive reactions to both D. pteronyssinus and D. farinae allergens using SPT among asthmatic patients in Gharbia Governorate, Egypt. [22] Similar results were reached by Haggag MG et al, 2017.Their study revealed that $62.5 \%$ of patients had positive family history.[23]

A detailed clinical history and physical examination followed by the detection of total serum IgE level and IgE immunoreactivity against specific allergens still represents the cornerstone in approaching allergic 
disorders.[4]

On comparing serum total immunoglobulin $\mathrm{E}(\mathrm{IgE})$ level between asthmatic patients and control subjects in the present study, asthmatic patients displayed a higher statistically significant level of serum total IgE. It was statistically significantly higher among male asthmatic patients. There was a positive correlation between total serum IgE level and asthma severity grade and skin prick test results.

Several studies disclosed high serum IgE levels among asthmatic patients. This is in alliance with Kim et al. 2013 who stated that the total IgE levels were significantly higher in males.[24] Fereidouni $\mathbf{M}$ et al.,2009 study uncovered that the mean total IgE serum was significantly high among asthmatics. Males had higher mean total IgE values than females ( $305 \mathrm{vs} 252 \mathrm{IU} / \mathrm{mL}, \mathrm{P}=0.6$ ), but the difference was not significant.[25]

On the contrary, Somani ,2008 demonstrated that total lgE level is higher in female patients and they attributed their results to the possibility that total levels of IgE might be inheritable, especially in females, because of the existence of two alleles at the X-linked locus.[26]

The disparity in the development of total IgE between males and females is the consequence of the fact that the levels of total IgE depend on many other factors; such as parasitic infestations, smoking, pollution, local diet and different genetic background in which males are at greater risk of exposure.[25]

$\lg \mathrm{E}$ is an antibody linked to allergic reactions and airway inflammation which is associated with asthma severity. IgE is also linked to airway hyperresponsiveness, and lower pulmonary function. Additionally, the use of monoclonal anti-IgE has resulted in decreasing asthma severity.

Concerning the correlation between level of total IgE and asthma severity, Kovač K et al,2007 also discerned that the greater the asthma severity the greater the total serum total $\operatorname{lgE}$ level $(>288.0 \mathrm{kIU} / \mathrm{L})$ and specific $\operatorname{lgE}$ to $D$ pteronyssinus ( $>44.1 \mathrm{kIUA} / \mathrm{L}$ ). They conducted a study to evaluate the correlation between serum total IgE level and asthma severity in asthmatic children sensitive to $D$ pteronyssinus.[27]

Kenawy et al., 2017 found a highly significant increase in serum level of IgE in patient with severe asthma than those with mild asthma with $P$ values $<0.001$.[28] Likewise, a study done by Rotsides and his coworkers (2010) reported a strong positive association between high IgE level and asthma severity in children and they proposed that serum IgE level is a strong predictor for allergy in asthmatic children. [29]

Regarding the relation between serum IgE level and the positivity of skin prick test, Baldacci S et al., 1996 concluded that the higher IgE levels the greater the positivity of SPT regardless the gender .[30] Rose et al., 1996 likewise assumed that there is some inverse relationship between the quantitative level of IgE antibody and the level of allergen necessary to cause symptoms of asthma.[31]

The impairment of the epithelial barrier is a corner stone in the development of allergic diseases. Increased intestinal permeability, either due to the exposure to antigens in asthmatic patients or due to a barrier defect, play a critical role in susceptibility to environmental allergens.[32] The process responsible for enhanced intestinal permeability in asthma is still indeterminate. There is an association between enhanced intestinal permeability and the severity of the asthma, airflow obstruction, which suggests that it is a bronchus to gut 
disease. [33] This could be attributed to the fact that mucosal defects can exist simultaneously in a lot organs and antigenic stimulation as well as environmental factors can result in its clinal expression in a single organ. [41]. For instance, identical histological mucosal changes have been observed in both duodenal and bronchial mucosa simultaneously.[5]

Therefore, correction of the gastrointestinal barrier defect is possibly an additional alternative approach for asthma treatment [34-36]. As it leads to reduction of epithelial liability to damage and resultant inflammatory and remodeling reaction. In addition to growth factors, several peptides can repair barrier function for example AT-1001, a peptide inhibitor of zonulin [35]. It is therefore essential to study serum zonulin level and its regulation in patients with asthma.

The present study disclosed that asthmatic patients displayed a higher statistically significant level of serum zonulin than control subjects. Patients living in rural areas had a significantly higher level on serum zonulin. Furthermore, there was a significant correlation between zonulin level and asthma grade. The higher the zonulin level the greater the grade of asthma severity. Nevertheless, we found that there was no difference in serum levels of zonulin subjects regarding gender and age. The cut of value of serum zonulin level to differentiate between grade 1-2 asthma severity and grade 3-4 asthma severity. In addition, serum zonulin showed a sensitivity equal to $80 \%$, a specificity equal to $71.4 \%$, a positive predictive value equal to $66.7 \%$ and a negative predictive value equal to $83.3 \%$. There was no statistically significant correlation to serum total IgE concentration. Grade of asthma had independent significant effect on zonulin level while serum total IgE had no significant effect on zonulin level via linear regression analysis.

A study conducted by Benard and colleagues to assess the intestinal permeability in asthmatics via administering oral radioactive CrEDTA and estimating its urinary recovery revealed that asthmatic patients had increased intestinal permeability in comparison. Unlike the current results, it was not correlated to the severity of asthma as deduced by pulmonary function test measurements or to the use of steroid treatment [37] This may be due to the difference in the method used to assess intestinal permeability.

Furthermore, a study performed by Cervantes-García D and collaborators aiming at assessing the outcome of oral Lactococcus lactis NZ9000 use on airway inflammation and lung remodeling in asthmatic rats and its relation to the preservation of the intestinal barrier, concluded that oral L. lactis could be used for asthma prevention through its maintenance of an adequately functioning intestinal barrier.[38]

Initial findings imply that a group of asthmatic patients has both high levels of serum zonulin and enhanced intestinal permeability [39]. These findings indicate that antigens presentation and subsequent lung inflammation occur as result of passage of antigens through lung and intestinal mucosa and submucosa and later stimulate the immune system resulting in lung inflammation [40].

Moreover, a study performed by Yamaide $\mathrm{F}$ et al. 2020 to examine the differences between serum zonulin level among allergic children and non- allergic children concluded that serum zonulin was significantly greater in children with allergy (Food allergy, Bronchial Asthma). In addition, it was significantly higher in patients with food allergy than in bronchial asthma patients. However, their results are not completely 
reliable as food allergy can be the main reason for increased intestinal permeability and this explains the higher increase in zonulin level among food allergy patients than among asthmatic ones. [32]

Up to the present moment no studies have been conducted to assess the relationship between serum zonulin level and asthma severity or to assess its correlation to different residential distribution. A study performed by Sheen et al to assess serum zonulin level in atopic dermatitis (AD) and its correlation to disease severity. They found that $A D$ group had a greater median serum zonulin level than the control group and serum zonulin level had significantly positive correlations with age and the SCORAD index, but not with total IgE, total eosinophil count (TEC), or the number of allergens to which a child is sensitized. And concluded that each $1 \mathrm{ng} / \mathrm{mL}$ increase in serum zonulin was associated with a 15\% greater risk of moderate-severe AD [6]. Their results agree with the current results as regards the correlation between serum zonulin level and total serum IgE level. Both revealed no statistically significant correlation.

\section{Conclusion}

Intestinal barrier dysfunction contributes in the pathogenesis of allergic asthma. Serum zonulin level reflects an increase in intestinal permeability and acts as prognostic factor of severity in Asthma. Correction of the gut barrier defect may be an additional novel approach for Asthma.

\section{Declarations}

Funding: none.

Conflicts of interest: none.

\section{Authors' contributions}

Shereen A. Baioumy, Shereen Mahmoud Ibrahim, Aya Elgendy and Shaimaa Fouad designed the study. Shereen A. Baioumy and Shaimaa Fouad Fouad shared in sample collection. Shereen Mahmoud Ibrahim and Aya Elgendy shared in sample collection and did the statistical analysis. Shaimaa Hani Fouad wrote the draft. Shereen A. Baioumy and Aya Elgendy performed the critical review of the manuscript. All authors reviewed and approved the final version. All authors read and approved the final manuscript.

\section{Acknowledgements}

None

\section{Availability of data and materials}

All the data needed to support the current findings could be found in a supporting sheet.

\section{Consent for publication}

Not applicable 


\section{Ethical approval and consent to participate}

The study was approved by the institutional review board (IRB) no \#6856/14-12-2020, Faculty of medicine, Zagazig University. An informed written consent was obtained from all parents at time of recruitment. This study was conducted in accordance with the Declaration of Helsinki.

\section{References}

1. Zhu X, Cui J, Yi L, Qin J. et al. The Role of T Cells and Macrophages in Asthma Pathogenesis: A New Perspective on Mutual Crosstalk. Mediators Inflamm.2020; 7835284. https://doi.org/10.1155/2020/7835284.

2. Trompette A, Divanovic $S$, Visintin A. et al. Allergenicity resulting from functional mimicry of a Toll-like receptor complex protein. Nature. 2009;457:585-8.

3. Taha A, Etewa S, Abdel-Rahman S. et al. House dust mites among allergic patients at the Allergy and Immunology Unit, Zagazig University: an immunologic and serologic study. J Parasit Dis. 2018;42(3):405-15. https://doi.org/10.1007/s12639-018-1016-9.

4. Breiteneder $\mathrm{H}$, Peng $\mathrm{YQ}$, Agache I. et al. Biomarkers for diagnosis and prediction of therapy responses in allergic diseases and asthma. Allergy. 2020;75(12):3039-68.

5. Ohlsson B, Orho-Melander M, Nilsson PM. Higher levels of serum zonulin may rather be associated with increased risk of obesity and hyperlipidemia, than with gastrointestinal symptoms or disease manifestations. Int J Mol Sci. 2017;18(3):582.

6. Sheen $\mathrm{YH}$, Jee HM, Kim DH. et al. Serum zonulin is associated with presence and severity of atopic dermatitis in children, independent of total IgE and eosinophil. Clin Exp Allergy. 2018;48:1059-62. DOI:10.1111/cea.13158.

7. National Institutes of Health. Global Initiative for Asthma. Global Strategy for Asthma Management and Prevention Revision. 2020. http://www.ginaasthma.org.

8. Bernstein IL, Li JT, Bernstein DI. et al. Allergy diagnostic testing: An updated practice parameter. Ann Allergy Asthma Immunol. 2008;100:1-148.

9. Australasian Society of Clinical Immunology and Allergy (ASCIA) Skin Prick Testing Guide for Diagnosis of Allergic Disease the ASCIA website. (2020) .

10. Bateman ED, Hurd SS, Barnes PJ. et al. Global strategy for asthma management and prevention: GINA executive summary. Eur Respir J. 2008;31(1):143-78. 10.1183/09031936.00138707.

11. Dhaliwal AK, Singh D, Randhawa RK. et al. Sensitivity in allergic asthmatic subjects towards house dust mite allergens. Systematic Applied Acarology. 2021;26(1):75-84.

12. Chu HT, Tran TN, Doyen V, et al. The protective effect of rural life on mite sensitization disappears among urban migrants in the South of Vietnam. World Allergy Organization Journal. 2019;12:100085. http://doi.org/10.1016/j.waojou.2019.100085.

13. Walker J, Dieleman L, Mah D. et al. High prevalence of abnormal gastrointestinal permeability in moderate-severe asthma. Clin Invest Med. 2014;1:E53-7. 
14. Ricciardolo FL, Levra S, Sprio AE. et al. Asthma in the real-world: the relevance of gender. Int Arch Allergy Immunol. 2020;181(6):462-6. doi:10.1159/000506808.

15. Sabry EY. Relation of perimenstrual asthma with disease severity and other allergic co-morbidities (The first report of perimenstrual asthma prevalence in Saudi Arabia). Allergol Immunopathol. $2011 ; 39(1): 23-36$.

16. Senna G, Latorre M. Bugiani M., et al. Sex differences in severe asthma: results from severe asthma network in Italy-SANI. Allergy, Asthma Immunology Research. 2021; 13(2), 219.

17. Holmquist L. and Vesterberg O.Immunochromatographic direct sampling on filter testing for aeroallergens. J Biochem Biophys Methods. 2003;57(3):183-90.

18. Hijazi N, Abalkhail B, and Seaton A. Diet and childhood asthma in a society in transition: a study in urban and rural Saudi ArabiaThorax 2000;55:775-9. https://doi.org/ 10.1136/thorax.55.9.775.

19. Henszel Ł, Kalisińska E, Kosik-Bogacka DI. et al. Mites in Dust Samples Collected from Sleeping Places in Apartments. Polish Journal of Environmental Studies. 2010;19(4).

20. Lawson JA, Rennie DC, Cockcroft DW. et al. Childhood asthma, asthma severity indicators, and related conditions along an urban-rural gradient: a cross-sectional study. BMC pulmonary medicine. 2017 Dec;17(1):1-9.

21. Hassan AA, Hagrass SA. Prevalence of bronchial asthma in primary school children. Am J Med Sci. 2017;7(2):67-73.

22. Antonios SN, Ashour DS, Elkholy MG. et al. House dust mites as a risk factor in chest allergic patients in Gharbia Governorate, Egypt. J Egypt Med Microbiol. 2012;21(1):51-62.

23. Haggag MG, Aboelazm AA, Al-Gazzar AM. et al. Immunoblotting technique versus skin prick test for detection of allergen specific immunoglobulin e in allergic conjunctivitis. Journal of ophthalmology related sciences. 2017;1(2):39-50.

24. Kim EJ, Kwon JW, Lim YM. et al. Assessment of total/specific lgE levels against 7 inhalant allergens in children aged 3to 6 years in Seoul, Korea. Allergy Asthma Immunol Res. 2013;5(3):162-9.

25. Fereidouni M, Hossini RF, Azad FJ. et al. Skin prick test reactivity to common aeroallergens among allergic rhinitis patients in Iran. Allergologia et immunopathologia. 2009;37(2):73-9.

26. Somani VK. A study of allergen-specific IgE antibodies in Indian patients of atopic dermatitis. Indian J Dermatol Venereol Leprol. 2008;4(2):100-4.

27. Kovač K, Dodig S, Tješić-Drinković D. et al. Correlation between asthma severity and serum IgE in asthmatic children sensitized to Dermatophagoides pteronyssinus. Archives of medical research. 2007 Jan 1;38(1):99-105.

28. Kenawy EM, El-Hafeez H, Mohamed NA. et al. Interleukin (il)-17 as a biomarker in assessment of bronchial asthma severity. Al-Azhar Med. J.2017; 46(2),, 443-454. DOI: 10.12816/0038267.

29. Rotsides DZ, Goldstein IF, Canfield SM. et al. Asthma, allergy, and IgE levels in NYC head start children. Respir Med. 2010;104(3):345-55.

30. Baldacci S, Modena P, Carrozzi L. et al. Skin prick test reactivity to common aeroallergens in relation to total IgE, respiratory symptoms, and smoking in a general population sample of northern Italy. Allergy. 
1996 Mar;51(3):149-56.

31. Rose G, Arlian L, Bernstein D. et al. Evaluation of household dust mite exposure and levels, of specific IgE and IgG antibodies in asthmatic patients enrolled in a trial of immunotherapy. J ALLERGY CLIN IMMUNOL. 1996;97(5):1071-8.

32. Yamaide F, Fikri B, Nakano T. et al. Serum zonulin levels are higher in pediatric allergic patients than those in healthy children. Authorea Preprints. 2020 Jun 28.

33. Djukanovic R, Roche WR, Wilson JW. et al. Mucosal inflammation in asthma. Am Rev Respir Dis. 1990;142:434-57.

34. Hijazi Z, Molla AM, Al-Habashi H, et al. Intestinal permeability is increased in bronchial asthma. Arch Dis Child.2004;89:227-229. doi: 10.1136/adc.2003.027680 Int. J. Mol. Sci.,18, 582; doi:10.3390/ijms18030582.

35. Swindle EJ. Collins JE, and Davies DE. Breakdown in epithelial barrier function in patients with asthma: Identification of novel therapeutic approaches. J Allergy Clin Immunol. 2009;124:23-34. doi:10.1016/j.jaci.2009.05.037.

36. Paterson BM, Lammers KM, Arrieta MC. et al. The safety, tolerance, pharmacokinetic and pharmacodynamic effects of single doses of AT-1001 in coeliac disease subjects: a proof of concept study. Aliment Pharmacol Ther. 2007;26:757-66.

37. Benard A, Desreumeaux P, Huglo D. et al. Clinical aspects of allergic disease Increased intestinal permeability in bronchial asthma. The Journal Of Allergy Clinical Immunology. 1996;97(6):1173-8.

38. Cervantes-García D, Jiménez M, Rivas-Santiago CE. et al. Lactococcus lactis NZ9000 prevents asthmatic airway inflammation and remodelling in rats through the improvement of intestinal barrier function and systemic TGF- $\beta$ production. Int Arch Allergy Immunol. 2021;182(4):277-91.

39. Fasano A Zonulin and its regulation of intestinal barrier function: the biological door to inflammation, autoimmunity, and cancer. Physiol Rev 2011; 91:151 - 75. PMID:21248165; http://dx.doi. org/10.1152/physrev.00003.2008.

40. Sturgeona C. Zonulin, a regulator of epithelial and endothelial barrier functions, and its involvement in chronic inflammatory diseases. review Tissue barriers. 2016;4(4):e1251384. http://dx.doi.org/10.1080/21688370.2016.1251384. (19 pages), and Fasanoa A..

41. Knutson TW, Bengtsson U, Dannaeus A, et al. Intestinal reactivity in allergic and nonallergic patients: an approach to determine the complexity of the mucosal reaction. Journal of allergy and clinical immunology. 1993 Feb 1;91(2):553-9.

42. Musken $\mathrm{H}$, Fernandez-Caldas E, Maranon F. et al.In vivo and in vitro sensitization to domestic mites in German urban and rural allergic patients. J Investig Allergol Clin Immunol. 2002;12:177-81.

\section{Tables}

Table (1): Description of studied subjects: : 


\begin{tabular}{|c|c|c|c|c|}
\hline Variable & $\begin{array}{l}\text { Control } \\
\text { Group }(n=48)\end{array}$ & Percentage\% & $\begin{array}{l}\text { Asthmatic patients } \\
(\mathrm{n}=48)\end{array}$ & Percentage\% \\
\hline $\begin{array}{l}\text { Sex: } \\
\text { Male } \\
\text { Female }\end{array}$ & $\begin{array}{l}28 \\
20 \\
\end{array}$ & $\begin{array}{l}85.3 \% \\
14.7 \% \\
\end{array}$ & $\begin{array}{l}18 \\
30 \\
\end{array}$ & $\begin{array}{l}37.5 \% \\
62.5 \% \\
\end{array}$ \\
\hline $\begin{array}{l}\text { Age (years): } \\
\mathrm{X} \pm \mathrm{SD} \\
\text { Median }\end{array}$ & $\begin{array}{l}32.7 \pm 11.2 \\
28\end{array}$ & & $\begin{array}{l}30.67 \pm 15.609 \\
30\end{array}$ & \\
\hline $\begin{array}{l}\text { Residence: } \\
\text { Rural } \\
\text { Urban } \\
\end{array}$ & $\begin{array}{l}34 \\
14 \\
\end{array}$ & $\begin{array}{l}70.8 \% \\
29.2 \% \\
\end{array}$ & $\begin{array}{l}26 \\
22 \\
\end{array}$ & $\begin{array}{l}54.16 \% \\
45.84 \% \\
\end{array}$ \\
\hline $\begin{array}{l}\text { Family history of atopy } \\
\text { Positive: } \\
\text { Negative: }\end{array}$ & $\begin{array}{l}11 \\
37\end{array}$ & $\begin{array}{l}22.9 \% \\
77 \%\end{array}$ & $\begin{array}{l}39 \\
9\end{array}$ & $\begin{array}{l}81.3 \% \\
18.8 \%\end{array}$ \\
\hline $\begin{array}{l}\text { Skin prick: } \\
\text { negative } \\
\text { positive }\end{array}$ & $\begin{array}{l}48 \\
0\end{array}$ & $\begin{array}{l}100 \% \\
0 \%\end{array}$ & $\begin{array}{l}0 \\
48\end{array}$ & $\begin{array}{l}0 \% \\
100 \%\end{array}$ \\
\hline $\begin{array}{l}\text { House dust Mites } \\
\text { D. pteronyssinus } \\
\text { D. farina } \\
\text { Both } \\
\end{array}$ & -- & - & $\begin{array}{l}48 \\
\\
34 \\
29 \\
34 \\
\end{array}$ & $\begin{array}{l}100 \% \\
70.8 \% \\
60.4 \% \\
70.8 \% \\
\end{array}$ \\
\hline \multirow{4}{*}{ Asthma grade } & \multicolumn{2}{|c|}{ asthma grade 1} & 4 & $8.3 \%$ \\
\hline & \multicolumn{2}{|c|}{ asthma grade 2} & 24 & $50.0 \%$ \\
\hline & \multicolumn{2}{|c|}{ asthma grade 3} & 12 & $25.0 \%$ \\
\hline & \multicolumn{2}{|c|}{ asthma grade 4} & 8 & $16.7 \%$ \\
\hline
\end{tabular}

Table (2): Comparison between Total IgE levels and zonulin levels among both control and case groups:

\begin{tabular}{|l|l|l|l|l|}
\hline Variable & $\begin{array}{l}\text { Control } \\
\text { Group 1 (n=48) }\end{array}$ & $\begin{array}{l}\text { Asthmatic patients } \\
\text { Group 2 (n=48) }\end{array}$ & F & P \\
\hline $\begin{array}{l}\text { Total IgE level (IU/ml) } \\
\text { Mean } \pm \text { SD }\end{array}$ & $84.4 \pm 18.6$ & $223.3 \pm 103.4$ & $\mathbf{4 . 8}$ & $0.000 \mathrm{HS}$ \\
\hline $\begin{array}{l}\text { Zounlin (ng/ml) } \\
\text { Mean } \pm \text { SD }\end{array}$ & $80 \pm 13$ & $258.3 \pm 153.01$ & 6.12 & $0.000 \mathrm{HS}$ \\
\hline
\end{tabular}

Table (3) Factors affecting Total IgE level: 


\begin{tabular}{|c|c|c|c|c|c|}
\hline \multicolumn{2}{|c|}{ Variables } & \multicolumn{2}{|c|}{ Total IgE } & Test value & $P$ value \\
\hline \multirow[t]{2}{*}{ Sex } & male & 272.89 & 141.33 & \multirow[t]{2}{*}{$2.29 *$} & \multirow[t]{2}{*}{$0.03 \mathrm{~S}$} \\
\hline & female & 193.53 & 56.38 & & \\
\hline \multirow[t]{2}{*}{ Residence } & urban & 219.27 & 93.30 & \multirow[t]{2}{*}{$0.25 *$} & \multirow[t]{2}{*}{$0.81 \mathrm{NS}$} \\
\hline & rural & 226.69 & 112.99 & & \\
\hline \multirow[t]{2}{*}{ Age } & $<30$ Years & 240.00 & 120.07 & \multirow[t]{2}{*}{$1.12 *$} & \multirow[t]{2}{*}{$0.27 \mathrm{NS}$} \\
\hline & $>30$ years & 206.58 & 82.78 & & \\
\hline \multirow[t]{4}{*}{ Asthma grade } & asthma grade 1 & 154.50 & .58 & \multirow[t]{4}{*}{$5.77 * *$} & \multirow[t]{4}{*}{$0.02 \mathrm{~S}$} \\
\hline & asthma grade 2 & 205.87 & 88.23 & & \\
\hline & asthma grade 3 & 241.08 & 113.93 & & \\
\hline & asthma grade 4 & 283.25 & 132.03 & & \\
\hline \multirow[t]{2}{*}{ Skin prick } & \begin{tabular}{|l|} 
negative \\
\end{tabular} & 172.00 & 34.37 & \multirow[t]{2}{*}{$3.33 *$} & \multirow[t]{2}{*}{$0.002 \mathrm{HS}$} \\
\hline & positive & 244.41 & 114.85 & & \\
\hline
\end{tabular}

*Student t test $\quad * *$ One Way ANOVA test (post hoc test shows significant difference between grade 1 vs grade 2)

Table (4) Factors affecting Zonulin level:

\begin{tabular}{|c|c|c|c|c|c|}
\hline & \multicolumn{2}{|c|}{ Zonulin level } & \multirow[t]{2}{*}{ Test value } & \multirow[t]{2}{*}{$P$ value } \\
\hline & & Mean & SD & & \\
\hline \multirow[t]{2}{*}{ Sex } & male & 290.11 & 163.89 & \multirow[t]{2}{*}{$1.12 *$} & \multirow[t]{2}{*}{$0.27 \mathrm{NS}$} \\
\hline & female & 239.27 & 145.59 & & \\
\hline \multirow[t]{2}{*}{ Residence } & urban & 315.55 & 157.34 & \multirow[t]{2}{*}{$2.51 *$} & \multirow[t]{2}{*}{$0.02 \mathrm{~S}$} \\
\hline & rural & 209.92 & 133.81 & & \\
\hline \multirow[t]{2}{*}{ Age } & $<30$ Years & 261.67 & 152.41 & \multirow[t]{2}{*}{$0.15^{*}$} & \multirow[t]{2}{*}{$0.88 \mathrm{NS}$} \\
\hline & $>30$ years & 255.00 & 156.83 & & \\
\hline \multirow[t]{4}{*}{ Asthma grade } & asthma grade 1 & 127.50 & 8.66 & \multirow[t]{4}{*}{$64.54^{* *}$} & \multirow[t]{4}{*}{$<0.001 \mathrm{HS}$} \\
\hline & asthma grade 2 & 209.50 & 103.91 & & \\
\hline & asthma grade 3 & 218.50 & 75.50 & & \\
\hline & asthma grade 4 & 530.00 & 87.83 & & \\
\hline \multirow[t]{2}{*}{ Skin prick } & negative & 299.29 & 182.05 & \multirow[t]{2}{*}{$1.20 *$} & \multirow[t]{2}{*}{$0.24 \mathrm{NS}$} \\
\hline & positive & 241.47 & 138.88 & & \\
\hline & & \multicolumn{2}{|c|}{ Zonulin level } & & \\
\hline \multirow[t]{2}{*}{ Total IgE } & Pearson Correlation & \multicolumn{2}{|c|}{0.14} & & \\
\hline & P value & \multicolumn{2}{|c|}{$0.34 \mathrm{NS}$} & & \\
\hline
\end{tabular}

*Student t test $\quad * *$ One Way ANOVA test (post hoc test shows significant difference between grade 1 vs grade 2 , grade 1 vs grade 3 , grade 1 vs grade 4 , grade 2 vs grade 4 and grade 3 vs grade 4)

Table 5: Linear regression analysis for factors affecting Zonulin level: 


\begin{tabular}{|c|c|c|c|c|c|c|}
\hline & \multicolumn{2}{|c|}{$\begin{array}{l}\text { Unstandardized } \\
\text { Coefficients }\end{array}$} & \multirow{2}{*}{$\begin{array}{c}\text { Standardized } \\
\text { Coefficients }\end{array}$} & \multirow[t]{2}{*}{ Sig. } & \multicolumn{2}{|c|}{$\begin{array}{c}\text { 95.0\% Confidence Interval for } \\
\text { B }\end{array}$} \\
\hline & B & Std. Error & & & Lower Bound & Upper Bound \\
\hline $\begin{array}{c}\text { Grade } 3 \text { or } \\
4\end{array}$ & 167.317 & 29.962 & 0.838 & $\begin{array}{c}<0.001 \\
\text { HS }\end{array}$ & 107.007 & 227.628 \\
\hline Total IgE & 0.075 & 0.183 & 0.062 & 0.684 NS & -.293 & 0.443 \\
\hline
\end{tabular}

Table (6): Validity of Zonulin level for differentiation between (grade 1 or 2) vs (grade 3 or 4 )

\begin{tabular}{|c|c|c|c|c|c|c|c|c|c|}
\hline \multirow[b]{2}{*}{ Parameters } & \multirow{2}{*}{ Cut off point } & \multirow{2}{*}{ AUC } & \multirow[b]{2}{*}{ Sig } & \multirow[t]{2}{*}{ Sensitivity } & \multirow[t]{2}{*}{ Specificity } & \multirow[t]{2}{*}{$+\mathrm{PV}$} & \multirow[t]{2}{*}{$-P V$} & \multicolumn{2}{|c|}{ 95\% Confidence Interval } \\
\hline & & & & & & & & Lower Bound & Upper Bound \\
\hline Zonulin & $\geq 198$ & 0.764 & $.002 \mathrm{HS}$ & $80 \%$ & $71.4 \%$ & $66.7 \%$ & $83.3 \%$ & 0.622 & 0.906 \\
\hline
\end{tabular}

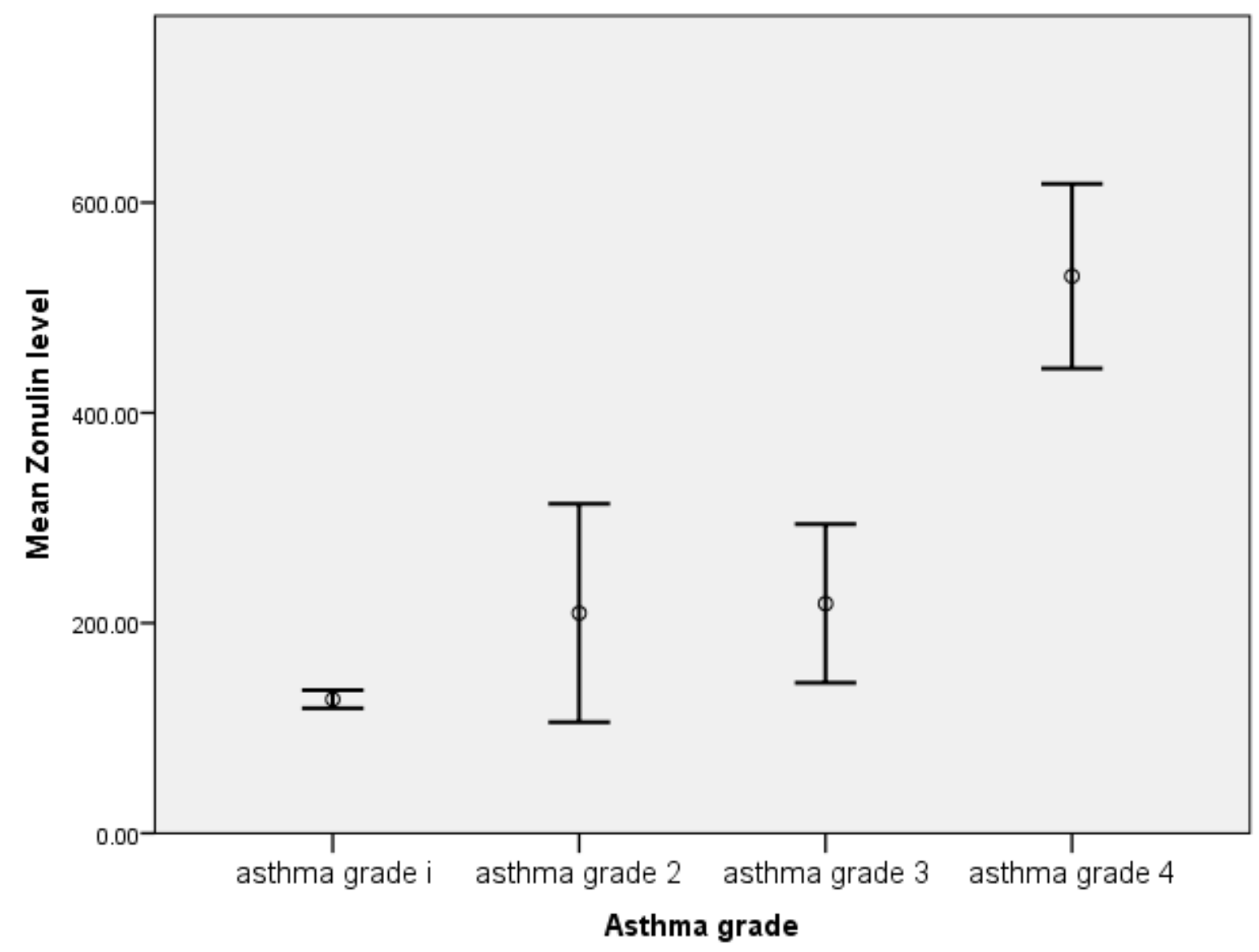

Error Bars: +/- 1 SD

Figure 1

Correlation between asthma grade of severity and serum zonulin level. 


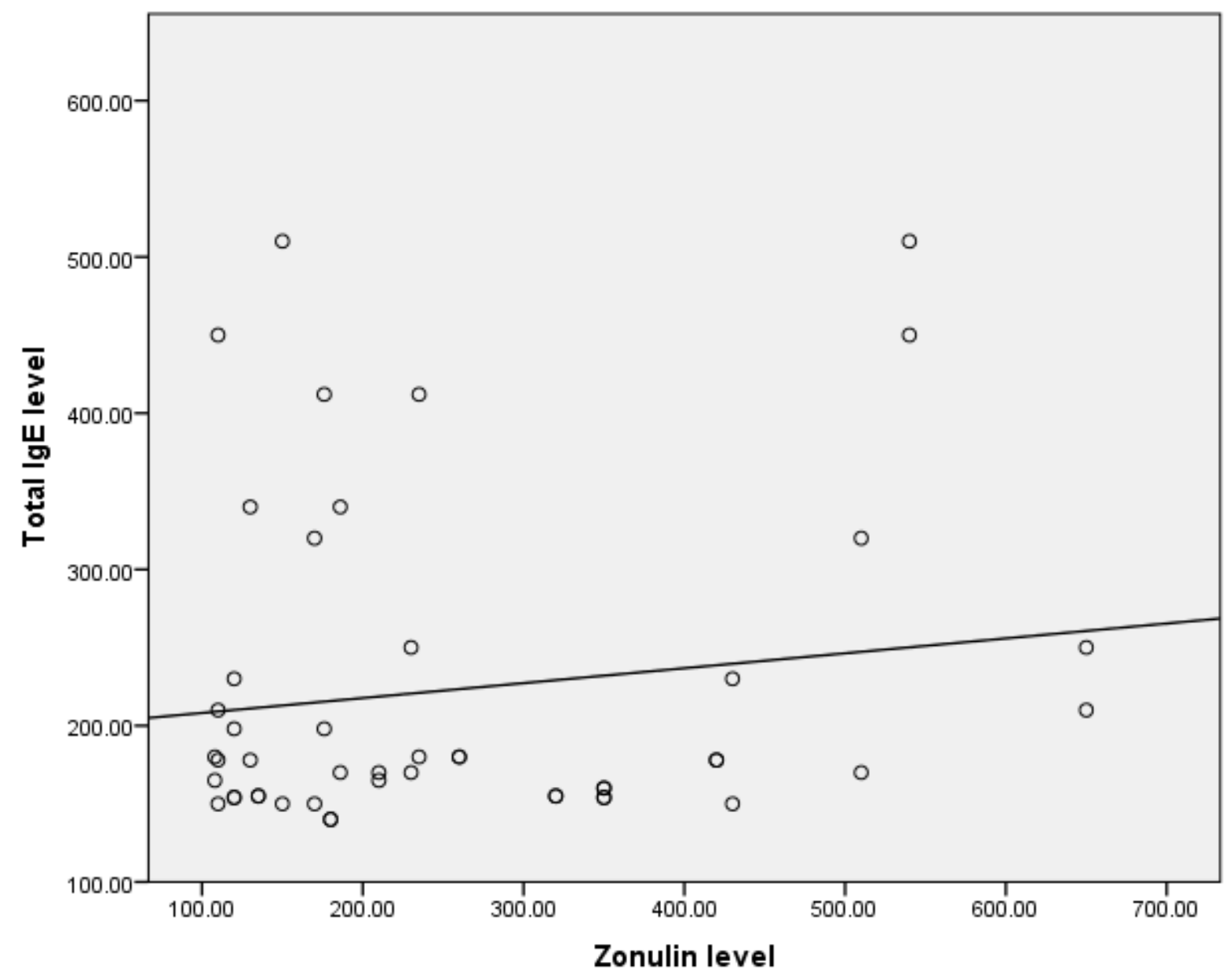

Figure 2

Correlation between serum zonulin level and total serum IgE level. 


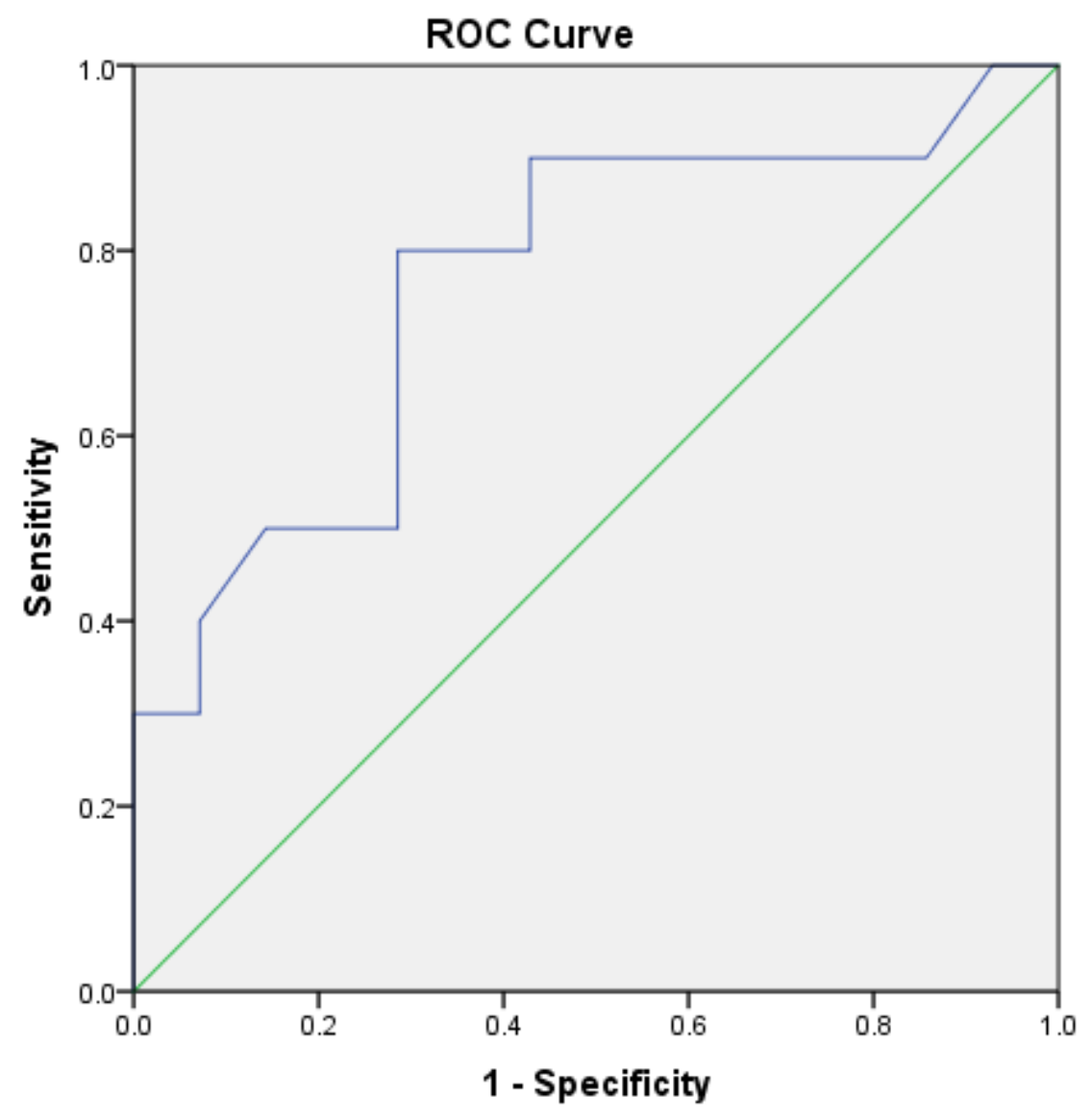

Diagonal segments are produced by ties.

\section{Figure 3}

Roc curve of Zonulin level for differentiation between (grade 1 or 2 ) vs (grade 3 or 4 ) 